\title{
Hepatitis B: knowledge and awareness among preclinical year medical students
}

\author{
Mohan B. Sannathimmappa, Vinod Nambiar, Rajeev Arvindakshan ${ }^{1}$
}

Department of Microbiology and Immunology, College of Medicine and Health Sciences, National University of Science and Technology, Sohar Campus, Sultanate of Oman, ' Department of Community and Family Medicine, All India Institute of Medical Sciences and Research Centre, Mangalagiri, Andhra Pradesh

\begin{tabular}{|c|}
\hline Access this article online \\
\hline Website: www.avicennajmed.com \\
\hline DOI: 10.4103/ajm.AJM_164_18 \\
\hline Quick Response Code: \\
\hline
\end{tabular}

\begin{abstract}
Background and Objective: Hepatitis B is an occupational health hazard to health-care workers. The complete knowledge of hepatitis B virus (HBV) transmission and prevention is indispensable for medical students. This study was conducted to assess the knowledge and awareness of hepatitis B among preclinical year medical students. Materials and Methods: This is a descriptive cross-sectional study. A predesigned self-administered questionnaire concerning hepatitis B knowledge and awareness was distributed to all the preclinical year medical students. The data were collected, tabulated, and analyzed by Microsoft Excel and Statistical Package for the Social Sciences (SPSS) software, version 22. The results were expressed in numbers and percentages. Results: Of 251 students, only 132 students voluntarily participated in the study. Majority of the students (84.8\%) were aware of HBV infection. Many students knew that blood transfusion (81.1\%) and use of contaminated needles and syringes (74.2\%) are major modes of transmission. However, less than $30 \%$ of the students had knowledge about other modes of transmission. More than $50 \%$ of the students lacked in their knowledge about clinical features and complications of hepatitis B infection. Majority of students (72.7\%) were aware of HBV vaccination. However, many students did not know their vaccination status, whereas only $23.5 \%$ of the students were fully immunized. Conclusion: This study revealed lack of complete knowledge regarding hepatitis $B$ among preclinical year medical students. They are at high risk of acquiring HBV infection during their clinical practice, later in life. Hence, implementation of well-structured education program in the first year itself is needed to create complete awareness among medical students about hepatitis B.
\end{abstract}

Key words: Blood transfusion, cirrhosis, jaundice, liver cancer, vaccination

\section{INTRODUCTION}

Hepatitis B virus (HBV) infection is a major global health problem affecting large number of people every year. ${ }^{[1]}$ HBV primarily targets liver and can cause both acute and chronic liver disease. HBV infection is asymptomatic in majority of the people and the chronic infection may lead to serious complications such as cirrhosis of the liver and hepatocellular carcinoma. ${ }^{[2-4]}$ As per the latest World Health

Address for correspondence: Dr. Mohan B. Sannathimmappa, Department of Microbiology and Immunology,

College of Medicine and Health Sciences,

National University of Science and Technology,

P. O. Box: 391, Postal Code: 321, Al Tareef,

Sohar, Sultanate of Oman.

E-mail:drmohan123@gmail.com
Organization (WHO) report, dated July 18, 2018: globally, by the end of 2015, an estimated 257 million people were living with $\mathrm{HBV},{ }^{[5]}$ and approximately 887,000 death ${ }^{[5]}$ have occurred, largely because of chronic complications of HBV infection such as hepatic cirrhosis and liver cancer. The virus transmits through blood and other body fluids from the

This is an open access journal, and articles are distributed under the terms of the Creative Commons Attribution-NonCommercial-ShareAlike 4.0 License, which allows others to remix, tweak, and build upon the work non-commercially, as long as appropriate credit is given and the new creations are licensed under the identical terms.

For reprints contact: reprints@medknow.com

Cite this article as: Sannathimmappa MB, Nambiar V, Arvindakshan R. Hepatitis B: Knowledge and awareness among preclinical year medical students. Avicenna J Med 2019;9:43-7. 
infected persons. Use of contaminated needles for injections, blood transfusion, sexual contact, and vertical transmission from mother to fetus are the most common routes of transmission. ${ }^{[6-9]} \mathrm{HBV}$ infection is an occupational hazard and the risk in health-care professionals is 2-10 times higher than the general population. ${ }^{[10-12]}$ Health-care workers and medical students in clinical years, who come in contact with the patients and their potentially infectious materials such as blood and other body fluids, are at highest risk of acquiring the infection and should be protected ${ }^{[13]}$ Medical students form the integral part of health-care system and they must have a proper knowledge about hepatitis B infection, modes of transmission, clinical features, complications, and preventive measures. The proper knowledge helps them to take necessary precautions to prevent the disease and also to spread awareness about hepatitis B infection among public, patients, and other health-care professionals. ${ }^{[14]}$

Vaccination and the use of personal protective equipment are the two major weapons for the prevention of hepatitis B infection. Recombinant hepatitis B vaccine, which is licensed for use, is advised for all health-care workers and medical students. ${ }^{[15-19]}$ Three doses of vaccine at 0,1 , and 6-12 months are recommended for optimum protection. This research was intended to assess the knowledge and awareness regarding hepatitis B among preclinical year students (fourth and fifth-year medical students) of College of Medicine and Health Sciences (CMHS), National University of Science and Technology (NUST), Oman, Sultanate of Oman.

\section{MATERIALS AND METHODS}

Study design: It was a descriptive cross-sectional study conducted at CMHS during the academic year 2017-2018. The study group included all the preclinical year students (year 4 and year 5). The study was approved by the Institutional Research and Ethics Committee, and it was conducted after obtaining necessary informed consent from the students. A notice regarding the study was circulated to all the preclinical year students through proper channels of the Microbiology and Immunology department, and all efforts were made to make them participate in the study voluntarily. A predesigned self-administered questionnaire confined to knowledge and awareness regarding hepatitis $\mathrm{B}$, its modes of transmission and prevention, and their vaccination status was prepared in a Microsoft Word document and distributed in a lecture hall to all the participants on a prenotified date and time. The data were collected, tabulated, and statistically analyzed using Microsoft Excel and Statistical Package for the Social Sciences (SPSS) software, version 22. IBM Chicago. Quantitative data were expressed in numbers and percentages.

\section{RESULTS AND ANALYSIS}

A total of 132 students voluntarily participated in the study. Data regarding knowledge and awareness of hepatitis B among students of preclinical years is described in Tables 14 . The data reveal that majority $(84.8 \%)$ of students were aware of hepatitis B and $77.3 \%$ believed that it is an infectious disease. Among the participants, $71.2 \%$ knew that hepatitis $\mathrm{B}$ is caused by a virus and approximately $70.5 \%$ of the participants stated that doctors and medical students are at risk of acquiring hepatitis $B$ from the infected patients.

Regarding the modes of transmission of hepatitis B infection, $81.06 \%$ and $74.1 \%$ of the students had a correct knowledge that it is transmitted through blood transfusion and by the use of contaminated syringes and needles, respectively. The knowledge of the students about other modes of transmission such as sexual contact (28.8\%), mother to baby (23.5\%), and piercing and tattoo (31.1\%) was weak. Twenty-eight percent of the students incorrectly stated that it can be transmitted through contaminated food and water, though hepatitis B is not a food and waterborne disease.

The clinical features of acute hepatitis B infection are not well understood by majority of the students. Approximately, threefourth of students $(72.7 \%)$ knew that it can cause jaundice. However, their knowledge about other clinical manifestations such as fever (42.4\%), loss of appetite (25.8\%), and nausea and vomiting $(28.0 \%)$ is poor. In addition, $81.1 \%$ of the students did not know that hepatitis B infection is often asymptomatic in majority of the patients. The students' knowledge about chronic complications associated with hepatitis B infection is also poor as only $49.2 \%$ and $25.8 \%$ of the students correctly
Table I: Statements regarding basic knowledge about hepatitis B

\begin{tabular}{|c|c|c|c|}
\hline \multirow[t]{2}{*}{ Statement } & \multicolumn{3}{|c|}{ Students' responses $(n=132)$} \\
\hline & Yes & No & Do not know \\
\hline Have you heard about hepatitis B infection? & II 2 (84.8\%) & $20(15.2 \%)$ & - \\
\hline Is hepatitis B an infectious disease? & $102(77.3 \%)$ & $18(13.6 \%)$ & $12(9.1 \%)$ \\
\hline What is the causative agent of hepatitis B? & Virus, 94 (7I.2\%) & Bacteria, 35 (26.5\%) & Parasite, 3 (2.3\%) \\
\hline $\begin{array}{l}\text { Do you think doctors and medical students are at risk of acquiring hepatitis B } \\
\text { infection from the patients? }\end{array}$ & $93(70.5 \%)$ & $24(18.2 \%)$ & $15(11.36 \%)$ \\
\hline
\end{tabular}


stated that cirrhosis of the liver and liver cancer, respectively, are the common associated complications.

Approximately four-fifth of the students (81.1\%) knew that hepatitis B is a preventable disease. Most of the students have well understood that screening of blood donors (81.1\%), vaccination $(72.7 \%)$, and use of sterile needles and syringes (74.2\%) are important preventive measures. The use of personal protective equipment, such as gloves, caps, masks, and gowns, as preventive measure was indicated only by $53.8 \%$ of the students. Less than half of the participants (40.2\%) stated

\begin{tabular}{|c|c|c|}
\hline \multirow[t]{2}{*}{ Statement } & \multicolumn{2}{|c|}{$\begin{array}{l}\text { Students' responses } \\
\qquad(n=132)\end{array}$} \\
\hline & Yes & No \\
\hline Blood transfusion & $107(81.1 \%)$ & $25(18.9 \%)$ \\
\hline $\begin{array}{l}\text { Use of contaminated syringes and } \\
\text { needles }\end{array}$ & $98(74.2 \%)$ & $34(25.8 \%)$ \\
\hline Sexual contact with infected person & $38(28.8 \%)$ & 94 (7I.2\%) \\
\hline $\begin{array}{l}\text { Vertical transmission (from mother } \\
\text { to fetus) }\end{array}$ & $31(23.5 \%)$ & I0I (76.5\%) \\
\hline Piercing and tattoo & $4 \mid$ (3I.I\%) & 91 (68.9\%) \\
\hline $\begin{array}{l}\text { Consumption of contaminated food } \\
\text { and water }\end{array}$ & $37(28.0 \%)$ & $95(72.0 \%)$ \\
\hline
\end{tabular}

\begin{tabular}{|c|c|c|}
\hline \multirow[t]{2}{*}{ Statement } & \multicolumn{2}{|c|}{$\begin{array}{l}\text { Students' responses } \\
\qquad(n=132)\end{array}$} \\
\hline & Yes & No \\
\hline $\begin{array}{l}\text { What are the signs and symptoms that } \\
\text { can be seen in acute hepatitis B infection? }\end{array}$ & $56(42.4 \%)$ & $76(57.6 \%)$ \\
\hline Fever: $56(42.42 \%)$ & $34(25.8 \%)$ & $98(74.2 \%)$ \\
\hline Loss of appetite: 34 (25.76\%) & $37(28.0 \%)$ & 95 (72.0\%) \\
\hline Nausea and vomiting: 37 (28.03\%) & $96(72.7 \%)$ & $36(27.3 \%)$ \\
\hline Jaundice: 96 (72.72\%) & $107(81.1 \%)$ & 25 (I8.9\%) \\
\hline $\begin{array}{l}\text { Most of the patients with chronic } \\
\text { hepatitis B infection are symptomatic: }\end{array}$ & $65(49.2 \%)$ & $67(50.8 \%)$ \\
\hline $\begin{array}{l}\text { Do you think chronic hepatitis B infection } \\
\text { can lead to cirrhosis of the liver? }\end{array}$ & $34(25.8 \%)$ & 98 (74.24\%) \\
\hline $\begin{array}{l}\text { Do you think chronic hepatitis B infection } \\
\text { can lead to liver cancer? }\end{array}$ & $56(42.4 \%)$ & $76(57.6 \%)$ \\
\hline
\end{tabular}

they had taken vaccine. Of that, only 31 (23.5\%) students stated that they are fully immunized with three doses of vaccine.

\section{DISCUSSION}

Exposure to blood-borne pathogens, such as HBV and human immunodeficiency virus, constitutes a significant occupational health hazard to health-care professionals. ${ }^{[20]}$ The knowledge, attitude, and practice (KAP) surveys are important tools to identify the problems, recommend solutions, and implement policies. ${ }^{[20]}$ The data of KAP surveys on hepatitis B among medical students in this part of Oman are unavailable, and hence this study was sought to assess the knowledge and awareness about hepatitis $\mathrm{B}$ among preclinical year students of CMHS. The results of our study warrant health awareness and vaccination drive to protect future budding doctors against $\mathrm{HBV}$ infection to which they are likely to encounter in their medical career. ${ }^{[21]}$

CMHS follows a 7-year medical degree program and the curriculum includes foundation, premed, preclinical, and clinical courses. During premed and preclinical years, students learn about basic sciences before they enter into clinical years where they study clinical subjects and approach patients.

The WHO has set a goal to eliminate viral hepatitis by 2030 , and the lack of general knowledge and awareness about HBV infection seems to be a hurdle for achieving this goal. ${ }^{[22]}$ The overall knowledge about HBV, its modes of transmission, and prevention is deficient among our study participants, but it is acceptable for the preclinical students as they are in the beginning of their medical course. However, a scientific and precise knowledge about $\mathrm{HBV}$ is highly essential for a medical student as it transmits 2-10 times higher in medical professionals. ${ }^{[9,10]}$ In this study, it was good to observe that majority of the respondents were aware of hepatitis B (84.8\%) and its causative agent (71.2\%), which is in line with the results of similar other studies. ${ }^{[23-25]}$

\begin{tabular}{|c|c|c|c|}
\hline \multirow[t]{2}{*}{ Statement } & \multicolumn{3}{|c|}{ Students' responses } \\
\hline & Yes & No & Do not know \\
\hline Is hepatitis B infection preventable? & $107(81.1 \%)$ & $6(4.5 \%)$ & $19(14.4 \%)$ \\
\hline \multicolumn{4}{|c|}{ Which of the following is/are preventive measures for hepatitis B infection? } \\
\hline Wearing gloves, caps, masks, gowns, and goggles & $7 \mathrm{l}(53.8 \%)$ & $21(15.9 \%)$ & $40(30.3 \%)$ \\
\hline Proper cooking of food & $34(25.76 \%)$ & $56(42.4 \%)$ & $32(24.2 \%)$ \\
\hline Vaccination & 96 (72.72\%) & $6(4.5 \%)$ & $30(22.7 \%)$ \\
\hline Use of sterile needles and syringes & $98(74.24 \%)$ & $15(11.4 \%)$ & $19(14.4 \%)$ \\
\hline Screening blood donor & $107(81.06 \%)$ & $5(3.8 \%)$ & $20(15.1 \%)$ \\
\hline Have you ever been vaccinated against hepatitis B? & $53(40.15 \%)$ & $19(14.39 \%)$ & $60(45.45 \%)$ \\
\hline \multicolumn{4}{|l|}{ If yes, how many doses of vaccine have you taken? } \\
\hline One dose & $13(9.85 \%)$ & - & - \\
\hline Two doses & $9(6.82 \%)$ & - & - \\
\hline Three doses & 31 (23.48\%) & - & - \\
\hline
\end{tabular}


Hepatitis $B$ is an occupational health hazard for health-care workers, and meticulous knowledge about its transmission and preventive measures among medical students is highly recommended. ${ }^{[20]}$ In a study conducted by Ibrahim and Idris, ${ }^{[14]} 71.1 \%$ of the students believed that health-care workers are at risk of acquiring infection from the infected patients as compared to $70.45 \%$ of the students correctly responding in our study. This study shows lack of knowledge among medical students with regard to different modes of transmission of HBV. The knowledge about transmission through blood products $(81.1 \%)$ and use of contaminated needles and syringes (74.2\%) among our study cohort is fairly good. However, awareness about other modes of spread-by sexual contact with an infected person (28.8\%), vertical transmission $(23.5 \%)$, and by piercing and tattoo (31.1\%) was low. Several studies in other countries too have revealed similar lack of knowledge among medical students. ${ }^{[19-22,24,25]}$ It was surprising to observe that minority of students (28.0\%) had a misconception that HBV spreads by contaminated food and water. Similar misconception among medical students was noticed by Aslam et al. ${ }^{[26]}$ The precise knowledge about the modes of transmission among medical students necessitates them to take protective measures during their clinical postings and also spread awareness among other health-care workers and general public.

This study also assessed the students' knowledge regarding clinical features and complications of hepatitis B infection. $\mathrm{HBV}$ primarily affects liver, and patients with acute infection present with clinical features such as fever, malaise, loss of appetite, nausea and vomiting, and jaundice. Hepatitis $\mathrm{B}$ infection is often asymptomatic in majority of the patients, and chronic infection ultimately may lead to severe complications such as cirrhosis and hepatocellular carcinoma, which are associated with high mortality rate. Among study population, significant percentage of students knew that jaundice $(72.7 \%)$ is one of the clinical sign. But their knowledge about other clinical features of acute hepatitis is low, ranging from $25 \%$ to $42 \%$. Majority of the students $(81.06 \%)$ were unaware that hepatitis B infection is often asymptomatic. With regard to chronic complications, more than $50 \%$ of the students were unaware that it leads to life-threatening complications such as cirrhosis (49.2\%) and hepatocellular carcinoma (27.8\%). Similar findings were reported in a study conducted on Syrian medical students. ${ }^{[14]}$

This study revealed surprising results with significant percentage of medical students who are not vaccinated (14.4\%) or not sure about their vaccination status (45.5\%), which makes them vulnerable to hepatitis B. However, survey results revealed that majority of them were aware of availability of HBV vaccine. Similar findings were published in a study conducted at College of Medical and Health sciences, Wollega University, Ethiopia ${ }^{[19]}$ Hepatitis B is a vaccine-preventable disease and the protective levels of anti-hepatitis B surface antibodies (anti-HBs) antibodies gradually decline to unprotected levels over 5-10 years in vaccinated individuals. ${ }^{[27]}$ Therefore, it is emphasized to mandate all medical students to test their antiHBs levels as they represent a high-risk population. ${ }^{[14,28]} \mathrm{On}$ the basis of immune status and previous vaccination history, medical students are advised for boosters, vaccination, or revaccination.

Another issue raised from the results of this study is that medical students lack knowledge and awareness about HBV transmission, its life-threatening complication, and the need for health education on HBV. Hence, it is highly advocated that CMHS must make reforms in its educational curriculum to promote knowledge and awareness among medical students. In addition, educational reforms should also be focused toward avoiding infection and seeking immediate medical care in case of accidental exposures to infected blood and other body fluids. Furthermore, institution should take initiatives to check the students' immune status and provide free vaccination to needy students.

Limitation of the study: This study did not measure anti-HBs antibody level to know the immune status of the participants against hepatitis B. It is recommended for further studies to estimate anti-HBs levels in the serum of students to know their actual immune status against hepatitis B.

\section{CONCLUSION}

The precise knowledge and awareness about hepatitis $\mathrm{B}$ among preclinical year students at CMHS is lacking. The study findings highlight the necessity of health education programs for students in the first year itself to improve their knowledge and awareness of this infectious disease. The proper knowledge helps them to take necessary precautions during patient care in their clinical years and also to disseminate knowledge and spread awareness about hepatitis B among other health-care workers and general public. It is also recommended that institution should take an initiative in measuring hepatitis B immune status of the students at the time of their entry into medical course and providing free HBV vaccines to all the incompletely vaccinated and non-vaccinated students.

Financial support and sponsorship Nil. 


\section{Conflicts of interest}

There are no conflicts of interest.

\section{REFERENCES}

1. Goldstein ST, Zhou F, Hadler SC, Bell BP, Mast EE, Margolis HS. A mathematical model to estimate global hepatitis B disease burden and vaccination impact. Int J Epidemiol 2005;34:1329-39.

2. Ganem D, Prince AM. Hepatitis B virus infection-Natural history and clinical consequences. N Engl J Med 2004;350:1118-29.

3. Tripathy S, Pushpa SHC, Saha S, Shankar R, Singh VK. Study of immune response after hepatitis $B$ vaccination in medical students and health care workers. Indian J Prev Soc Med 2011;42:314-21.

4. Lavanchy D. Hepatitis B virus epidemiology, disease burden, treatment, and current and emerging prevention and control measures. J Viral Hepat 2004;11:97-107.

5. World Health Organization. Global hepatitis report. 2017. Available from: http://www.who.int/en/news-room/fact-sheets/detail/hepatitis-B/ WHO. [Last accessed on April 2017].

6. Hadler SC. Hepatitis B virus infection and health care workers. Vaccine 1990;8:S24-8; discussion S41-3.

7. Deisenhammer S, Radon K, Nowak D, Reichert J. Needle-stick injuries during medical training. J Hospital Infect 2006;63:263-7.

8. Hou J, Liu Z, Gu F. Epidemiology and prevention of hepatitis B virus infection. J Viral Hepat 2010;17:4-9.

9. Gheorghe L, Csiki IE, lacob S, Gheorghe C. The prevalence and risk factors of hepatitis B virus infection in an adult population in Romania: A nationwide survey. Eur J Gastroenterol Hepatol 2013;25:56-64.

10. Ha NB, Trinh HN, Nguyen TT, Leduc T-S, Bui C, Ha NB, et al. Prevalence, risk factors, and disease knowledge of chronic hepatitis $\mathrm{B}$ infection in Vietnamese Americans in California. J Cancer Educ 2013;28:319-24.

11. Araujo MW, Andreana S. Risk and prevention of transmission of infectious diseases in dentistry. Quintessence Int 2002;33:376-82.

12. María Elena CP, Eduardo GC, Gerardo SL, Irma PC, María Alicia DO, José Luís GR, et al. Hepatitis B surface antibodies in medical students from a public university in Puebla, Mexico. Hum Vaccines Immunother 2016;12:1857-62.

13. Geberemicheal A, Gelaw A, Moges F, Dagnew M. Seroprevalence of hepatitis B virus infections among health care workers at the Bulle Hora Woreda Governmental Health Institutions, Southern Oromia, Ethiopia. J Environ Occup Sci 2013;2:9-14.

14. Ibrahim N, Idris A. Hepatitis B awareness among medical students and their vaccination status at Syrian Private University. Hepat Res Treat 2014;2014:131920.
15. Centers for Disease Control and Prevention (CDC). Recommended Vaccines for Health Care Workers. Available from: http://www.cdc.gov/ vaccines/adults/rec-vac/hcw.html. [Last accessed on April 2017].

16. Sacchetto MS, Barros SS, Araripe Tde A, Silva AM, Faustino SK, da Silva JM. Hepatitis B: Knowledge, vaccine situation and seroconversion of dentistry students of a public university. Hepat Mon 2013;13:e13670.

17. Papagiannis D, Tsimtsiou Z, Chatzichristodoulou I, Adamopoulou, M, Kallistratos I, Pournaras S, et al. Hepatitis B virus vaccination coverage in medical, nursing, and paramedical students: A cross sectional, multicentered study in Greece. Int J Environ Res Public Health 2016;13:323.

18. Saini R, Saini S, Sugandha RS. Knowledge and awareness of Hepatitis B infection amongst the students of Rural Dental College, Maharashtra, India. Ann Niger Med 2010;4:18-20.

19. Mesfin YM, Kibret KT. Assessment of knowledge and practice towards hepatitis B among medical and health science students in Haramaya University, Ethiopia. PLoS One 2013;8:e79642.

20. Abdela A, Woldu B, Haile K, Mathewos B, Deressa T. Assessment of knowledge, attitudes and practices toward prevention of hepatitis $B$ virus infection among students of medicine and health sciences in northwest Ethiopia. BMC Res Notes 2016;9:410.

21. Rathi A, Kumar V, Majhi J, Jain S, Lal P, Singh S. Assessment of knowledge, attitude, and practices toward prevention of hepatitis $B$ infection among medical students in a high-risk setting of a newly established medical institution. J Lab Physicians 2018;10:374-9.

22. Karimi-Sari H, Bayatpoor ME, Aftabi Khotbesara M, Ebrahimi MS, Sattari Z, Sattari P, et al. Knowledge, attitude, and practice of Iranian health sciences students regarding hepatitis $B$ and $C$ virus infections: $A$ national survey. Am J Infect Control 2017;45:e135-41.

23. Anjali S, Shikha J. Prevention of hepatitis B; knowledge and practices among medical students. Health Line 2011;2:8-11.

24. Al-Jabri AA, Al-Adawi S, Al-Abri JH, Al-Dhahry SH. Awareness of hepatitis $B$ virus among undergraduate medical and non-medical students. Saudi Med J 2004;25:484-7.

25. Khan AM, Rahul B, Pawan P, Ahmad S. Do the medical, dental and nursing students of first year know about hepatitis B? A study from a university of North India. J Pak Med Assoc 2012;62:25-7.

26. Aslam G, Soniha A, Yasmeen I, Akhtar AS. Knowledge and awareness of hepatitis B among students of a public sector university. Isra Med J 2015;7:95-100.

27. Mahawal BS, Bhai N, Kataria VK, Gulati N, Chandola I. Estimation of anti-HBs antibody titer in adults during 5-10 years period following three doses of vaccine. IOSR J Pharm Biol Sci 2013;7:20-3.

28. Al Ghamdi SS, Fallatah HI, Fatyani DM, Al-Mughales JA, Gelaidin AT. Long term efficacy of the hepatitis B vaccine in a high risk group. J Med Virol 2013;85:1518-22. 